\title{
Germination as a processing technique for soybeans in small-scale farming
}

\author{
N.C. Kayembe ${ }^{\#}$ \& C. Jansen van Rensburg \\ Department of Animal and Wildlife Sciences, University of Pretoria, Pretoria 0002, South Africa
}

(Received 4 December 2013; Accepted 6 June 2013; First published online 15 June 2013)

Copyright resides with the authors in terms of the Creative Commons Attribution 2.5 South African Licence.

See: http://creativecommons.org/licenses/by/2.5/za

Condition of use: The user may copy, distribute, transmit and adapt the work, but must recognise the authors and the South African Journal of Animal Science.

\begin{abstract}
Heat processing is an effective way of reducing antinutritional factors (ANFs) in legumes, but requires expensive facilities and equipment. Accurate control of temperature is critical to avoid under- or overheating. Therefore, heat treatment of soybeans is not a viable option for the average small-scale farmer in remote areas. Germination and other traditional methods, namely soaking and dehulling, were evaluated as alternative processing methods for soybeans. The effect of the processing treatment on the level of different ANFs, nutritional composition and in vitro protein digestibility (IVPD) of soybean seeds was determined. Soybeans were soaked for 24 hours and allowed to germinate for one to six days. Soaked soybeans were manually dehulled. Changes within seeds were noted for nutritional and ANFs during germination. Crude protein and fat content increased with increasing number of days germinated, but germination caused a decrease in starch content. Dehulling also increased the crude protein and fat content of the seeds. All treatments caused a significant decrease in condensed tannins of the soybeans. Trypsin inhibitor levels were numerically lower after germinating, soaking and dehulling of seeds, but not significantly so. There were no changes in IVPD after treatment of the soybeans. It was concluded that germination for a period of three days effectively improved the nutritional value of soybeans and can be considered an alternative treatment of soybeans for the small-scale farmer where heat treatment is impractical or impossible.
\end{abstract}

Keywords: Soybeans seed, Glycine max, TIA, anti-nutritional factors, traditional methods

\#Corresponding author: ndonda.kayembe@gmail.com

\section{Introduction}

Legume seeds are important sources of energy and protein in many parts of the world, both in animal and human nutrition (Kaushik et al., 2010). However, their nutritional value may be compromised in part by the presence of undesirable components, known as antinutritional factors (ANFs) (Donangelo et al., 1995).

Processing legumes with heat is a quick technique for decreasing or destroying ANFs, but strict guidelines must be applied for the treatment to be effective. An optimal processing temperature must be applied, as overheating can cause protein and amino acid damage. On the other hand, underprocessing does not completely destroy ANFs (Kabeya \& Kiatoko, 2004). Expensive facilities and equipment are required for the proper heat treatment of legumes, putting this technique out of reach of the average small-scale farmer in remote areas.

Globally, soybean (Glycine max) seed is one of the largest sources of vegetable seed oil and protein in the feed and food industry, and contains about $40 \%$ crude protein and $20 \%$ oil. It is also a source of calcium, iron, carotene and ascorbic acid. Soybean oilcake meal has become the principal protein supplement for livestock in many countries (Ghaly \& Sutherland, 1982) and is one of the legumes that is most frequently used in the poultry industry. However, soybeans contain undesirable components such as lipoxygenase and trypsin inhibitors that limit their utilisation. Trypsin inhibitor is an ANF that affects protein digestibility (Kumar et al., 2006). A high level of trypsin inhibitors in a diet stimulates pancreatic juice secretion and 
causes pancreatic hypertrophy and poor growth in animals (Liener \& Kakade, 1980, cited by Huisman \& Tolman, 2001).

Traditional processing methods of soybeans such as germinating, soaking and dehulling are sometimes used to reduce or eliminate the ANFs that affect protein utilisation. The trial reported here was designed to evaluate the efficacy of germination and other traditional treatments as alternative processing methods in reducing the levels of ANFs in soybean seed.

\section{Materials and Methods}

One ton of soybean seeds (variety RR5409 Monsanto) was procured locally (Brits, North West Province, South Africa). The seeds were kept raw or subjected to one of four processing methods: roasted, soaked for one or two days, dehulled or germinated from one to six days. The methods of processing were as follows:

- As a heat-treated control group, a representative sample of seed was roasted in an oven for 30 min at $130{ }^{\circ} \mathrm{C}$. After cooling, the seeds were milled and stored in plastic bottles at room temperature for further analysis.

- For the soaking treatment, $500 \mathrm{~g}$ representative soybean samples were weighed into $5000 \mathrm{~mL}$ plastic containers, which were then filled with tap water. The seeds were soaked at room temperature for 24 or $48 \mathrm{~h}$. The soaked seeds were spread on hessian sacks for 48 to $72 \mathrm{~h}$ under sunlight until dry. After drying, the seeds were milled through a $1 \mathrm{~mm}$ sieve and kept in plastic containers at room temperature for further analysis.

- The soybean seeds were dehulled after being soaked for $24 \mathrm{~h}$ in tap water $(1: 10, \mathrm{w} / \mathrm{v})$. The hulls were removed manually by rubbing the seeds between the palms of the hands (Sangronis, 2007). After dehulling, the hulls were removed by flotation, and the cotyledons were dried under sunlight. The dehulled seeds were milled through a $1 \mathrm{~mm}$ sieve, and then stored at room temperature, pending further analysis.

- Germination was achieved by soaking the seeds for $24 \mathrm{~h}$. Afterwards they were spread indoors on hessian sacks on the floor, and covered with aluminium foil to exclude light. Six groups of seeds were kept at room temperature $\left(22-26{ }^{\circ} \mathrm{C}\right)$ and allowed to germinate for one to six days, respectively. Water was applied once daily to provide moisture during sprouting. Thereafter, the germinated beans were dried for 48 to $72 \mathrm{~h}$ under sunlight, ground through a $1 \mathrm{~mm}$ sieve, and then kept at room temperature pending further analysis.

The sampling of seeds was carefully conducted to ensure homogenous and representative samples for analysis. Large samples were collected from various locations from the original batch of beans, and were properly mixed, divided and subdivided until the required sample size was obtained.

All treatments were replicated four times, independent of one another. Representative samples from each treatment from all four batches were analysed in duplicate for moisture (AOAC, 2000), crude protein (AOAC, 2000), starch (Davie, 1986), condensed tannins (Porter et al., 1986), total polyphenols (Makkar, 1993), trypsin inhibitor activity (TIA) (Kakade et al., 1974), crude fat (AOAC, 2000) and in vitro protein digestibility. Analyses were done at the UP-Nutrilab (Department of Animal and Wildlife Sciences, University of Pretoria, South Africa).

In vitro protein digestibility (IVPD) of the seed was determined by pepsin or papain enzyme digestion. For the pepsin method, the soybeans ( $300 \mathrm{~g}$ ) were weighed into a series of test tubes. A solution of $5 \mathrm{~mL}$ of $0.075 \mathrm{~N} \mathrm{HCl}$ and $0.5 \mathrm{~mL}$ of pepsin solution $(2.0 \mathrm{mg} / \mathrm{mL})$ in $0.075 \mathrm{~N} \mathrm{HCl}$ was added to each tube. The tubes were incubated at $37^{\circ} \mathrm{C}$ and enzyme action was stopped after $24 \mathrm{~h}$ by adding $5 \mathrm{~mL} 10 \%(\mathrm{w} / \mathrm{v})$ trichloroacetic acid (TCA). Digestion was performed in duplicate. The digest was filtered through Whatman No. 2 filter paper, and the residue was washed with warm water on the filter. Nitrogen in the residue was estimated by the micro-Kjeldahl method. The IVPD was obtained by calculating the difference between the amount of total nitrogen in the sample before and after in vitro digestion with pepsin (AOAC, 1965). Kjeldahl nitrogen was multiplied by the factor 6.25 to obtain crude protein.

In vitro protein digestibility with papain was conducted according to the method used by Buchanan \& Byers (1969) and modified by Nanda et al. (1977). The activator solution of $0.5 \mathrm{M}$ thioglycolic acid was prepared by adding $4.6 \mathrm{~g}(3.5 \mathrm{~mL})$ laboratory-grade thioglycolic acid to distilled water and making it up to $100 \mathrm{~mL}$, after having adjusted the $\mathrm{pH}$ to 6.6 with a $0.45 \mathrm{M} \mathrm{NaOH}$ solution. A phosphate-citrate buffer 
solution of pH 6.6 was made by mixing 7.7 parts $0.2 \mathrm{M} \mathrm{Na}_{2} \mathrm{HPO}_{4}$ with 2.3 parts $0.1 \mathrm{M}$ citric acid. Quantities of substrate representing about $10 \mathrm{mg}$ of protein $\mathrm{N}$ were weighed accurately in $75 \mathrm{~mL}$ centrifuge tubes. Then $0.4 \mathrm{~mL}$ papain solution was pipetted into each digestion tube, together with $0.5 \mathrm{~mL} 0.5 \mathrm{M}$ thioglycolic acid and $9.1 \mathrm{~mL}$ citrate-phosphate buffer. Two drops of toluene were added as preservative, the tubes were stoppered, and the contents were mixed gently. Care was taken to ensure that all particles of the protein sample remained immersed in the digestion liquid. The samples were incubated in duplicate at $37{ }^{\circ} \mathrm{C}$ for $24 \mathrm{~h}$. The control tubes contained only enzyme, activator and buffer. Immediately after incubation, the unhydrolyzed protein fraction was precipitated by adding $10 \mathrm{~mL}$ trichloroacetic acid (TCA) solution (100 $\mathrm{g} / \mathrm{L})$ to each tube. Thereafter the procedure was followed as described for pepsin.

An analysis of variance with the GLM model (SAS, 2010) was used to determine the significance between treatments. Mean and standard deviations were calculated. Treatment means were separated using Fisher's protected least significant difference (LSD) at the 5\% level of significance.

\section{Results \& Discussions}

Soybeans were germinated for various time periods, from 1 to 6 days, in order to find the optimal germination period. Raw and roasted soybeans were used as negative and positive controls, respectively. Soaked and dehulled soybeans were also assessed for their nutritional value, levels of ANFs and in vitro protein digestibility.

The germinated soybeans contained less $(P<0.05)$ starch compared with all other treatments, including the raw beans (Table 1). Mubarak (2005) reported a decrease in starch content in mung bean seeds after three days of germination. Mwikya et al. (2000) also found a gradual decrease in the starch content of finger millet during the first $36 \mathrm{~h}$ of germination. This reduction was attributed to the hydrolysis of starch that supplies the developing seedling with energy during germination (Madden et al., 1985).

Crude protein was found to increase as the number of days of germination of soybeans increased (Table 1) and was higher $(P<0.05)$ than the crude protein content of beans from the raw control group and the roasted and soaked treatments. Kaushik et al. (2010) also reported an increase in crude protein with germination of soybeans. Similar increases in protein have been reported for other legumes such as lablab beans (Osman, 2007), mung beans (Mubarak, 2005), faba beans and kidney beans (Alonso et al., 1998). The apparent increase in protein can be attributed to the utilization of carbohydrates as an energy source for developing sprouts (Donangelo et al., 1995). However, Bamdad et al. (2009) reported a notable decrease in protein content after lentils germinated for 1, 3 and 5 days. Echendu et al. (2009) found a release of free amino acids after enzymatic hydrolysis for the synthesis of new protein.

Table 1 Effect of soaking, dehulling and germination of soybean seeds on crude protein, fat and starch content

\begin{tabular}{lccc}
\hline \multicolumn{1}{r}{ Treatment } & Crude protein & Crude fat & Starch \\
\hline Raw & $39.1^{\mathrm{a}} \pm 0.37$ & $15.8^{\mathrm{a}} \pm 1.34$ & $1.24^{\mathrm{ab}} \pm 0.11$ \\
Roasted & $40.3^{\mathrm{b}} \pm 0.57$ & $19.6^{\mathrm{b}} \pm 1.03$ & $1.38^{\mathrm{a}} \pm 0.20$ \\
Soaking - 1 day & $40.2^{\mathrm{b}} \pm 0.10$ & $17.7^{\mathrm{b}} \pm 0.82$ & $1.17^{\mathrm{b}} \pm 0.11$ \\
Soaking - 2 day & $42.1^{\mathrm{c}} \pm 0.25$ & $19.0^{\mathrm{c}} \pm 0.40$ & $0.96^{\mathrm{c}} \pm 0.03$ \\
Dehulling & $45.1^{\mathrm{d}} \pm 0.35$ & $21.0^{\mathrm{d}} \pm 0.54$ & $1.11^{\mathrm{bc}} \pm 0.12$ \\
Germination 1 day & $41.3^{\mathrm{e}} \pm 0.19$ & $18.1^{\mathrm{d}} \pm 0.89$ & $0.99^{\mathrm{d}} \pm 0.89$ \\
Germination 2 day & $42.2^{\mathrm{f}} \pm 0.54$ & $19.1^{\mathrm{e}} \pm 1.37$ & $0.84^{\mathrm{d}} \pm 0.12$ \\
Germination 3 day & $43.4^{\mathrm{g}} \pm 0.20$ & $19.2^{\mathrm{ef}} \pm 0.99$ & $0.75^{\mathrm{d}} \pm 0.10$ \\
Germination 4 day & $43.8^{\mathrm{g}} \pm 0.52$ & $19.2^{\mathrm{e}} \pm 1.05$ & $0.71^{\mathrm{d}} \pm 0.13$ \\
Germination 5 day & $44.1^{\mathrm{gh}} \pm 0.70$ & $18.5^{\mathrm{e}} \pm 0.97$ & $0.94^{\mathrm{d}} \pm 0.20$ \\
Germination 6 day & $45.1^{\mathrm{di}} \pm 0.30$ & $20.6^{\mathrm{f}} \pm 0.60$ & $0.86^{\mathrm{d}} \pm 0.24$
\end{tabular}

Mean ( \pm standard deviation) values within the same column with different superscripts differ significantly at $P<0.05$. 
Germination of the soybeans increased the fat contents significantly $(P<0.05)$ (Table 1$)$. This agrees with Echendu et al.'s (2009) report on ground beans. However, Ghavidel \& Prakash (2007) found a significant decrease of fat content after germination of some legume seeds. Osman (2007) and Mubarak (2005) reported a significant decrease of fat content when mung been seeds were allowed to germinate for three days. This could be owing to the use of fat as energy during the sprouting process. The other processing methods that were included in this study, that is, soaking, dehulling and roasting, led to significant increases of crude protein and fat content. These increases are owing to the removal of the hull portion and therefore the concentration of endosperm in the legume product (Ghavidel \& Prakash, 2007) as protein and fat are characteristically present in the cotyledon fraction of seeds (Alonso et al., 1998).

Table 2 shows the effect of the different treatments on the levels of various ANFs. The time of germination and the duration of soaking were important factors affecting the ANFs measured in the study. All treatments numerically decreased the activity of trypsin inhibitor measured in the soybeans. These differences did not prove to be statistically significant, probably because of large variations found among replicates. However, germination may be useful in removing or reducing the activity of trypsin inhibitors in soybeans.

Germination significantly reduced the levels of condensed tannins in the soybeans. Condensed tannins were significantly decreased by $46 \%, 55 \%$ and $54 \%$, respectively, after 2,3 and 4 days of germination. This reduction in tannin content in soybeans is attributed to the tannin activity during germination (Mubarak, 2005) that leads to the formation of hydrophobic association of tannins with seed proteins and enzymes. Some loss of condensed tannins during germination may be because of the leaching of tannins into water. Reddy et al. (1985) found that overnight soaking of grains followed by germination for two days significantly reduced the tannin content by $50 \%$ in a wide variety of legumes. The decrease in condensed tannins after soaking, as observed in this study, is in agreement with results reported by Alonso et al. (2000).

Dehulling decreased the levels of condensed tannins, similarly to the findings of Alonso et al. (1998). Tannins are located mainly in the seed coats, which could explain their reduction after dehulling (Matthäus \& Angelini, 2003).

Table 2 Effect of soaking, dehulling and germination of soybeans on trypsin inhibitor activity (mg/g), total polyphenols (\%) and condensed tannins (\%)

\begin{tabular}{lccc}
\hline Treatment & Trypsin inhibitor activity & Total polyphenols & Condensed tannins \\
\hline Raw & $83.1 \pm 8.71$ & $10.8^{\mathrm{a}} \pm 0.42$ & $1.24^{\mathrm{a}} \pm 0.34$ \\
Roasted & $52.3 \pm 14.55$ & $12.4^{\mathrm{b}} \pm 1.07$ & $1.50^{\mathrm{a}} \pm 0.46$ \\
Soaking - 1 day & $77.3 \pm 9.67$ & $12.4^{\mathrm{ab}} \pm 0.20$ & $1.04^{\mathrm{ab}} \pm 0.62$ \\
Soaking - 2 day & $66.2 \pm 5.31$ & $12.4^{\mathrm{ab}} \pm 1.56$ & $0.71^{\mathrm{c}} \pm 0.21$ \\
Dehulling & $68.7 \pm 9.20$ & $12.8^{\mathrm{ab}} \pm 1.35$ & $0.64^{\mathrm{c}} \pm 0.18$ \\
Germination 1 day & $64.0 \pm 24.97$ & $11.8^{\mathrm{ab}} \pm 0.24$ & $0.82^{\mathrm{c}} \pm 0.29$ \\
Germination 2 day & $67.9 \pm 21.54$ & $11.2^{\mathrm{ab}} \pm 0.77$ & $0.67^{\mathrm{c}} \pm 0.14$ \\
Germination 3 day & $64.4 \pm 18.86$ & $10.6^{\mathrm{ab}} \pm 0.69$ & $0.56^{\mathrm{c}} \pm 0.22$ \\
Germination 4 day & $69.0 \pm 8.35$ & $10.4^{\mathrm{ab}} \pm 0.70$ & $0.57^{\mathrm{c}} \pm 0.28$ \\
Germination 5 day & $63.9 \pm 6.67$ & $12.4^{\mathrm{bc}} \pm 1.41$ & $0.96^{\mathrm{c}} \pm 0.39$ \\
Germination 6 day & $67.3 \pm 10.77$ & $12.8^{\mathrm{ac}} \pm 0.69$ & $0.87^{\mathrm{c}} \pm 0.26$
\end{tabular}

Mean ( \pm standard deviation) values within the same column with different superscripts differ significantly at $P<0.05$.

In this study, the germination of soybean seeds did not have a significant effect on the level of total polyphenols in the beans. The increase of total polyphenols observed in the soybeans that were germinated for a period of five to six days could be attributed to the presence of fungi at this time (Wu et al., 2011), as 
fungal growth on the seeds was evident from the fifth day of germination. Further research is needed before definite conclusions can be made.

Various researchers have reported lower levels of tannins, TIA and other ANFs in pulses as a result of domestic processing, including soaking, dehulling and germinating. Mwikya et al. (2000) found that the TIA decreased threefold, and reported a significant decrease in tannins to undetectable levels in finger millet during sprouting. A 20\% - 38\% reduction in tannins was observed during the germination of green grams, cowpeas, lentils and chickpeas (Ghavidel \& Prakash, 2007). Sangronis \& Machado (2007) found a significant decrease of TIA in pigeon beans, white beans and black beans after five days of germination, while Frias et al. (1995) found that six days of germination of lentils decreased TIA. Wang et al. (1997) reported that TIA decreased with shorter germination periods, but increased slightly as the length of germination increased. In this study, the level of total polyphenols increased after five days of germination, and also after roasting, soaking and dehulling soybeans (Table 2). Changes in phenolic compounds may occur, depending on the types of seed (López-Amorós et al., 2006), processing conditions such as rinsing (Frias, 1995), presence of light, and germination time (Frias, 1995; Oloyo, 2004; López-Amorós et al., 2006; Dueňas et al., 2009). Oloyo, (2004) and Dueňas et al. (2009) found that polyphenols of lupin increased during germination. Similarly, Satwadhar et al. (1981) found that the polyphenol levels in moth beans increased from $1.0 \%$ to $1.7 \%$ at $36 \mathrm{~h}$ germination, while beans that germinated for $48 \mathrm{~h}$ had higher amounts of polyphenols than raw moth beans.

No significant differences were noted in IVPD among the treatments, regardless of the type of enzyme used (Table 3). On the contrary, Mubarak (2005) reported that dehulling, soaking and germinating mung bean seeds improved their IVPD. A significant increase was observed in the IVPD of white beans, black beans and pigeon beans after germination (Alonso et al., 2000; Sangronis \& Machado, 2007).

Table 3 Effect of soaking, dehulling and germination of soybeans on in vitro protein digestibility (\%)

\begin{tabular}{lll}
\hline Treatment & Pepsin digestion & Papain digestion \\
\hline Raw & $66.5 \pm 21.40$ & $62.7 \pm 13.01$ \\
Roasted & $44.6 \pm 19.79$ & $58.4 \pm 2.77$ \\
Soaking - 1 day & $65.4 \pm 24.44$ & $55.4 \pm 11.13$ \\
Soaking - 2 day & $80.0 \pm 7.03$ & $57.2 \pm 16.58$ \\
Dehulling & $71.9 \pm 24.69$ & $48.0 \pm 9.01$ \\
Germination 1 day & $64.6 \pm 14.02$ & $55.4 \pm 9.77$ \\
Germination 2 day & $63.8 \pm 15.96$ & $52.6 \pm 8.90$ \\
Germination 3 day & $59.8 \pm 19.38$ & $52.5 \pm 8.90$ \\
Germination 4 day & $57.8 \pm 15.15$ & $49.5 \pm 17.99$ \\
Germination 5 day & $58.1 \pm 14.36$ & $46.8 \pm 9.79$ \\
Germination 6 day & $62.8 \pm 11.47$ & $50.7 \pm 4.56$ \\
\hline
\end{tabular}

Mean ( \pm SD) reported on dry basis.

\section{Conclusion}

All traditional processing methods tested in this study significantly increased the crude protein and fat content of the soybeans, but decreased the starch content. Germination for a period of three to four days was effective in improving their nutritional value and reducing the levels of condensed tannins. Trypsin inhibitor activities were numerically lower in all treated soybeans, but not significantly. No statistical differences were noted between the soybeans that were germinated for a period of three days and those that were germinated for four days. Furthermore, longer periods of germination may result in fungal growth that may be detrimental to the quality of the soybeans. In this study, notable fungal growth after five days of germination might have contributed to an increase in the polyphenol content of the beans. It is recommended that small- 
scale farmers in rural areas apply a germination period of three days for soybeans when properly controlled heat treatment is not possible. The cost of germinating soybeans is minimal as expensive equipment and specialised facilities are not necessary. Because soybeans are used mostly in poultry diets, the findings of the study are probably most applicable in the field of poultry nutrition. However, in vivo studies on poultry are needed to substantiate the efficacy of germination as a processing method for soya.

\section{References}

Alonso, R., Orue, E. \& Marzo, F., 1998. Effect of extrusion and conventional processing methods on protein and ant nutritional factor contents in pea seeds. Food Chem. 63, 505-512.

Alonso, R., Aguirre, A. \& Marzo, F., 2000. Effects of extrusion and traditional processing methods on antinutrients and in vitro digestibility of protein and starch in faba and kidney beans. Food Chem. 68, 159-165.

AOAC, 1965. Official Method of Analysis $\left(10^{\text {th }}\right.$ ed.). Association of Official Analytical Chemists. Washington, D.C. 330.

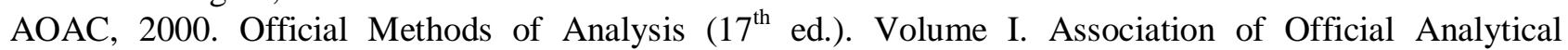
Chemists, Inc. Maryland, USA.

Buchanan, R.A. \& Byers, M., 1969. Interference by cyanide with the measurement of papain hydrolysis. J. Sci. Food Agric. 20, 364-367.

Davie, S.J., 1986. Laboratory Methods: Determination of Starch. Anim. Nutr. Sub., Animal and Dairy Science Research Institute, Irene, South Africa.

Donangelo, C.M., Trugo, L.C, Trugo, N.M.F. \& Eggum, B.O., 1995. Effect of germination of legume seeds on chemical composition and on protein and energy utilization in rats. ASA, Denmark.

Dueňas, M., Hernãndez, T., Estrella, I. \& Fernãndez, D., 2009. Germination as a process to increase the polyphenols content and antioxidant activity of lupin seeds (Lupinus angustifolius L.). Food Chem. 117, 599-607.

Echendu, C.A., Obizoba, I.C. \& Anyika, J.U., 2009. Effects of germination on chemical composition of grounbean (Kerstingiella geocarpa harm) seeds. Pak. J. Nutr. 8, 1849-1854.

Frias, J., Pollan., D., Hedley, C.L. \& Valverde, V., 1995. Evolution of trypsin inhibitor activity during germination of lentils. J. Agric. Food Chem. 43, 2231-2234.

Ghaly, T.F. \& Sutherland, J.W., 1982. Quality aspects of heated-air drying of soybeans. Victoria, Australia.

Ghavidel, R.A. \& Prakash, J., 2007. The impact of germination and dehulling on nutrients, antinutrients, in vitro iron and calcium bioavailability and in vitro starch and protein digestibility of some legume seeds. J. Food Sci. Nutr. 40, 1292-1299.

Huisman, J. \& Tolman, G.H., 2001. Antinutritional factors in the plant proteins of diets for non-ruminants. Recent Developments in Pig Nutrition 3, 261-291.

Kabeya, S. \& Kiatoko, M., 2004. Etude comparative de l'incorporation des graines de soja torréfiées, non traitées et germées dans l'alimentation des poulets de chair. Faculté des Sciences Agronomiques, University of Lubumbashi, Democratic Republic of Congo. (in French).

Kakade, M.L., Rackis, J.J., McGhee, J.E. \& Puski, G., 1974. Determination of trypsin inhibitor activity of soy products: A collaborative analysis of an improved procedure. Cereal Chem. 51, 376.

Kumar, V., Rani, A., Pandey, V. \& Chauhan, G.S., 2006. Changes in lipoxygenase isozymes and trypsin inhibitor activity in soybean during germination at different temperatures. Food Chem. 99, 563-568.

Kaushik, G., Satya, S. \& Naik, S.N., 2010. Effect of domestic processing techniques on the nutritional quality of soybean. Mediterr. J. Nutr. Metab. 3, 39-46.

López-Amorós, M.L., Hernóndez, T. \& Estrella, I., 2006. Effect of germination on legume phenolic compounds and their antioxidant activity. J. Food Compos. Anal. 19, 277-283.

Madden, M.A., Tan-Wilson, A.L. \& Wilson, K.A., 1985. Proteolysis of soybean Bowman-Birk trypsin inhibitor during germination. Phytochemistry 24, 2811-2815.

Makkar, H.P.S., 1993. Antinutritional factors in food for livestock. In: Animal Production in Developing Countries. Eds Gil, M., Owen, E., Pollot, G.E. \& Lawrence, T.L.S., Occasional Publication No 16. British Society of Animal Production. pp. 69-85.

Matthäus, B. \& Angelini, L.G., 2003. Anti-nutritive constituents in oilseed crops from Italy. Ind. Crop Prod. Germany. 
Mubarak, A.E., 2005. Nutritional composition and antinutritional factors of mung bean seeds (Phaseolus aureus) as affected by some home traditional processes. Food Chem. 89, 489-495.

Mwikya, S.M., Camp, J., Yiru, Y. \& Huyghebaert, A., 2000. Nutrient and antinutrient changes in finger millet (Eleusine coracan) during sprouting. Technol. 33, 9-14.

Nanda, C.L., Ternouth, J.H. \& Kondos, A.C., 1977. In vitro hydrolysis of plant concentrate with papain. J. Food Sci Agric. 28, 20-22.

Oloyo, R.A., 2004. Chemical and nutritional quality changes in germinating seeds of Cajanus cajaan L. Food Chem. 85, 497-502.

Osman, M.A., 2007. Effect of different processing methods, on nutrient composition, antinutritional factors, and in vitro protein digestibility of Dolichos lablab bean sweet. J. Nutr. 6, 299-303.

Reddy, N.R., Pierson, M.D., Sathe, S.K., \& Salunkhe, D.K., 1985. Chemical, nutritional and physiological aspects of dry bean carbohydrates - A review. Food Chem. 13, 25-68.

Sangronis, E. \& Machado, C.J., 2007. Influence of germination on the nutritional quality of Phaseolus vulgaris and Cajanus cajan. J. Food Sci. Agri. Technol. 40, 1.

Satwadhar, P.N., Kadam, S.S. \& Salunkhe, D.K., 1981. Effects of germination and cooking on polyphenols and in vitro digestibility of horse gram and moth bean. J. Plant Foods for Human Nutrition 31, 71-76.

SAS, 2010. Statistical Analysis systems User’s Guide: Statistics Version 8.13 SAS institute Inc. Cary, N.C., USA.

Wang, N., Lewis, M.G, Brennau, J.G. \& Westby, A., 1997. Optimization of germination process of cowpea by response surface methodology. Food Chem. 158, 329-339.

Wu, Z., Song, L. \& Huang, D., 2011. Polyphenolic antioxidants and phytoalexins changes in germinating legume seeds with food grade fungal Rhizopus oligoporus stress. $12^{\text {th }}$ Asian Food Conference 16-18 June, Thailand. 